heated in test tubes about one and one-half inches in diameter and six inches in length. About $60 \mathrm{cc}$. of oil were used in each case, the tubes being immersed in a bath of concentrated sulphuric acid and potassium bisulphate.

From these results it appears that, in general, the specific gravity, refractive index and free fatty acids increase, and the iodine value decreases as the temperature of heating increases. The decrease in the iodine value is quite rapid above $180^{\circ}$ and is influenced both by the temperature and duration of heating. The saponification equivalent remained practically constant throughout. The refractive index was dependent upon the temperature alone below $220^{\circ}$. Above this point the time of heating afiected it more than the temperature. Below $220^{\circ}$ there was little cliange in the free fatty acicls. Between $220^{\circ}$ and $240^{\circ}$ the acid percentage was more than doubled when the oil was heated for ten minutes, and after heating for thirty minutes the acidity was four times as great as in the original oil. At $270^{\circ}$ the acidity was nine and fifteen times as great as in the original oil, when heated for ten and thirty minutes respectively. The time of heating above $220^{\circ}$ therefore influences the acidity as much or more than the temperature.

While therefore the heating of cottonseed oil does change in some degree its physical and chemical constants, the changes are not sufficiently great to furnish a means of determining whether or not heat has been applied to it, because of the wide limits of these constants in normal unheated oils. In other words, a cottonseed oil which has been heated until its sensitiveness to Halphen's test has been destroved, and until it no longer reduces silver nitrate, will still give physical and chemical constants well within the limits shown by normal unheated oils, except in case of free fatty acids. However, if heated cottonseed oil should be mixed with olive oil, a determination of acidity would be of no value for proving its presence in the nixture, because the acidity of the latter usually exceeds the percentage found in the former even after heating at $270^{\circ}$ for thirty minutes.

Chemical laboratory, Washington state College, PUllman, Wash.

\title{
A METHOD FOR DETECTING SYNTHETIC COLOR IN BUTTER.
}

BY R. W. CORNELISON.

Received July 14, Igos.

In an effort to determine with certainty whether or not a particular sample of butter contained a synthetic dye the results obtained by methods given in the well-known works treating on the subject did not seem to the writer to be sufficiently conclusive. By Martin's method (shaking 
with alcohol containing some carbon disulphide) most of the color remained in the lower or fat layer. The alcoholic solution yielded very little color to silk. Geisler's test (fuller's earth) gave a negative result, but it is stated by Leach that some samples of fuller's earth do not react at all in this test. Low's method (sulphuric and acetic acids) gave a reddish brown acid.layer. It could hardly be called "Wine red." Doolittle's method (shaking the fat with dilute hydrochloric acid) gave a very faint pink, so faint indeed, that it could hardly be regarded as conclusive.

In view of these rather unsatisfactory results, several methods were devised and one of them seemed so promising that its publication is deemed worth while.

About ro grams of the clear dry fat are melted and well shaken in a separatory funnel with Io or 20 grams of glacial acetic acid, 99.5 per cent. If the materials are too hot the fat will dissolve, but at about $35^{\circ}$ it separates quickly and almost completely. The clear acid is drawn off, and, after noting its color, it is tested by the addition of a few drops of concentrated nitric acid to about $5 \mathrm{cc}$. of the acetic acid. The sample in question immediately gave a full and distinct pink coloration, which is permanent, for some hours, at least. Concentrated sulphuric acid gave a transient pink coloration, passing in a second or two into a brown. Slight dilution of the sulphuric acid retarded this latter change.

In order to test the method a sample of cream from grass-fed cows (during the last days of May) was churned in the laboratory and the yellow butter so obtained was used in all experiments recorded below. The synthetic colors were dissolved in cottonseed oil, I gram to I liter, and these solutions were used in coloring the butter. The synthetic dyes were added to the fat in the proportion of I to I00,000. The vegetable colors, except curcumin, which was from Eimer \& Amend, were prepared in the laboratory by extracting the dry material with ether, filtering and evaporating to dryness. The dry ether extract was dissolved in cottonseed oil and such an amount of this solution added to the melted fat as would produce a solution of one part of the coloring matter (ether extract) in 50,000 parts of butter. The results obtained are given below in tabular form. The abbreviations used will be readily understood.

The numbers given in brackets in the following table are those of the colors in Green's r 904 edition of Schultz and Julius.

The Soudan I (benzeneazo- $\beta$-naphthol) used was quite pure, having been prepared for the purpose.

The Butter Yellow (dimethylaminoazobenzene) was also prepared for the purpose but was not pure, as the dimethyl aniline at hand was very impure. 


\begin{tabular}{|c|c|c|c|c|c|}
\hline & $\begin{array}{l}\text { Coioring } \\
\text { matter. }\end{array}$ & $\begin{array}{c}\text { Color of } \\
\text { acid extract. }\end{array}$ & Conc. $\mathrm{HNO}_{3}$ & Conc. $\mathrm{H}_{2} \mathrm{SO}_{4}$. & $\begin{array}{l}\mathrm{H}_{2} \mathrm{SO}_{4} \text { and } \\
\text { lough ether to } \\
\text { lear solution. }\end{array}$ \\
\hline I & $\begin{array}{c}\text { Unknown } \\
\text { sample }\end{array}$ & $\begin{array}{l}\text { Strong orange- } \\
\text { yellow }\end{array}$ & $\begin{array}{l}\text { Strong } \\
\text { pink }\end{array}$ & $\begin{array}{l}\text { Strong salmon- } \\
\text { pink, changing } \\
\text { to brown. }\end{array}$ & Pink \\
\hline 2 & $\begin{array}{l}\text { Pure Natural } \\
\text { Butter (yellow) }\end{array}$ & Water white & Water white & $\begin{array}{l}\text { Faint pink after } \\
\text { a while. }\end{array}$ & Water white \\
\hline 3 & Soudan I (II) & Decided pink & Strong pink & Strong clear pink & Pink \\
\hline 4 & $\begin{array}{l}\text { Butter Yellow } \\
\text { (I6) }\end{array}$ & Very faint pink & Faint pink & Faint pink & Faint color. \\
\hline 5 & $\begin{array}{l}\text { Cerasine } \\
\text { Orange G. } \\
\text { (Cassella) (Io) }\end{array}$ & $\begin{array}{l}\text { Greenish yeilow, } \\
\text { strong. }\end{array}$ & $\begin{array}{l}\text { Acid yellow, } \\
\text { oil globule } \\
\text { salmon-pink. }\end{array}$ & $\begin{array}{l}\text { Same as with } \\
\mathrm{HNO}_{3} \text {. }\end{array}$ & $\begin{array}{l}\text { Brownish } \\
\text { yellow. }\end{array}$ \\
\hline 6 & $\begin{array}{l}\text { Yellow O. B. } \\
\text { (H. \& M.) }\end{array}$ & $\begin{array}{l}\text { Bright yellow, } \\
\text { not very strong }\end{array}$ & $\begin{array}{l}\text { Acid faint pink, } \\
\text { oil globule } \\
\text { salmon-pink. }\end{array}$ & $\begin{array}{l}\text { Similar to } \\
\mathrm{HNO}_{3} .\end{array}$ & Pink. \\
\hline 7 & $\begin{array}{l}\text { Yellow A. B. } \\
\text { (H. \& M.) }\end{array}$ & $\begin{array}{l}\text { Warm ochre- } \\
\text { yellow, weak. }\end{array}$ & $\begin{array}{l}\text { Pink, fat } \\
\text { colorless }\end{array}$ & $\begin{array}{l}\text { Brownish pink, } \\
\text { oil faint pink. }\end{array}$ & Pink. \\
\hline 8 & Annatto. & Dull yellow & Little change & $\begin{array}{l}\text { Faint pink } \\
\text { after a while }\end{array}$ & $\begin{array}{l}\text { Very faint } \\
\text { yellow. }\end{array}$ \\
\hline 9 & Curcumin & $\begin{array}{l}\text { Intense greenish } \\
\text { yellow. }\end{array}$ & $\begin{array}{c}\text { Dull ochre- } \\
\text { yellow. }\end{array}$ & Strong pink & Yellow. \\
\hline IO & Carrot & $\begin{array}{l}\text { Very faint } \\
\text { greenish yellow }\end{array}$ & $\begin{array}{l}\text { Faint } \\
\text { yellow. }\end{array}$ & $\begin{array}{l}\text { Faint pink } \\
\text { after a while. }\end{array}$ & $\begin{array}{l}\text { Very faint } \\
\text { yellowish. }\end{array}$ \\
\hline I I & $\begin{array}{l}\text { "Alderney Butter } \\
\text { Color" (H. \& M }\end{array}$ & $\begin{array}{l}\text { Brownish } \\
\text { I.) yellow. }\end{array}$ & Strong pink & Strong pink & \\
\hline I2 & $\begin{array}{l}\text { Ranson's Butter } \\
\text { Color ("Vege- } \\
\text { table") }\end{array}$ & Yellow & $\begin{array}{l}\text { Almost de- } \\
\text { colorized. }\end{array}$ & Same as $\mathrm{HNO}_{3}$. & \\
\hline I3 & $\begin{array}{l}\text { "Dandelion } \\
\text { Brand" Butter } \\
\text { Color ("Vegetab }\end{array}$ & Yellow & $\begin{array}{l}\text { Almost de- } \\
\text { colorized }\end{array}$ & Same as $\mathrm{HNO}_{3}$, & \\
\hline
\end{tabular}

The Cerasine Orange G (benzeneazoresorcinol), Yellow O. B. (o-toluidineazo- $\beta$-naphthalamine), and Yellow A. B. (anilineazo- $\beta$-naphthalamine) were trade samples of unknown purity. The first was obtained from the Cassella Color Company and the two latter from Messrs. Heller and Merz.

It will be noted that nitric acid gives the best differentiation between the synthetic colors tried and those of regetable origin. Attention is directed to the reaction of curcumin with sulphuric acid.

It is perfectly evident that the list of colors investigated does not comprise all the colors that are or may be used for coloring butter. It is hoped, however, that the data given will prove of some value.

Before concluding, the writer would like to make a strong plea for more care in properly identifying colors in published papers on the subject. He has in mind now several excellent papers which have doubt- 
less been the product of much work on the part of their authors and which are rendered almost useless by the fact that the colors are designated by fanciful names peculiar to the output of one firm. In one case in mind, the firm, whose colors are treated at some length, probably does not make one gram of dye. The dyes are purchased and, after being "reduced" and suitably compounded, are sold under coined names. The confusion of well-known trade names as given in Allen or Schultz and Julius is bad enough. Besides this, it is certainly a fact that many of the colors sold by the large manufacturers under well-known names are mixtures. Some days ago the writer received a line of eosine samples from one of the largest manufacturers. Each had a definite and familiar name, but upon further inquiry it was admitted that three out of five were mixtures. In view of these facts it would seem very necessary that more attention should be given to the identity and purity of colors used in constructing tables for their detection and identification.

NEW YORK LABORATORY, BUREAU OF CHEMISTRY,

U. S. DEPARTMENT OF AGRICULTURE.

\section{COMPOSITION OF KNOWN SAMPLES OF PAPRIKA.}

By $R$ E. DOOIITTLE AND A. W. OGDEN.

Received July $14,1908$.

Because of cheaper labor in the countries of production, practically all paprika reaches the markets of this country in a ground state, and like other ground spices it is more or less subject to sophistication. Being valued for its sweet flavor and high color the temptation to add artificial coloring matter to inferior grades to make them appear of a higher grade is very great and is quite commonly practiced. The color of the inferior grades is also brought up by grinding the pods with olive oil. The various grades of paprika are produced by selection of pods and the removal of the stems and seeds therefrom, for it is in the seeds and placentae to which the seeds are attached that are located the sharp and pungent properties of the fruit, which are not desired in the finished product. The finer grades of paprika are, therefore, produced by grinding the selected, well ripened and highly colored pods from which the stems and more or less of the seeds are removed. The lower grades are from the lower grade pods, from which the seeds or even the stems are not removed or to which the superfluous seeds and stems of the finer grades are sometimes added. By these various sortings and mixtures, products of all grades and prices are produced, even to the so-called "Mercantile" grade, which is composed entirely of ground stems and other refuse.

In order that we might have at hand reliable data by which to judge the character of the importations of the ground paprika presented for entry to this country we secured direct from the producers large samples 